\title{
Targeted therapies in the treatment of advanced basal cell carcinoma
}

\author{
Michael R. Migden* \\ Departments of Dermatology and Head and Neck Surgery, MD Anderson Cancer Center, Houston, TX USA
}

\begin{abstract}
Objective: To review available treatment options for the management of advanced basal cell carcinoma (BCC) with a focus on hedgehog inhibitor therapies.

Methods: A MEDLINE search of hedgehog inhibitors in the treatment of advanced BCC was conducted.

Results: BCC is the most commonly diagnosed skin cancer worldwide. While the majority of BCC can be effectively treated with standard surgical excision, Mohs surgery, curettage and electrodessication, radiotherapy, and/or superficial field therapies, rarely, patients develop advanced BCC (ie, locally advanced or metastatic BCC), which can be associated with treatment challenges and poor outcomes. Among several therapies being investigated for the treatment of advanced BCC, hedgehog pathway inhibitors have emerged as an important treatment option for this population. Vismodegib and sonidegib are currently the only hedgehog pathway inhibitors approved for the treatment of certain subsets of patients with advanced BCC. Clinical efficacy and safety data from the pivotal phase 2 clinical trials of vismodegib and sonidegib in patients with advanced BCC are reviewed. Data on other hedgehog inhibitors (eg, taladegib, patidegib, itraconazole, posaconazole) are also presented. Because resistance to hedgehog inhibitors may occur, use of novel combinations and/or immunotherapy strategies are also being evaluated.
\end{abstract}

Conclusions: Hedgehog pathway inhibitors have an established efficacy and safety profile and have become an important treatment option for patients with advanced BCC. The optimal use of hedgehog pathway inhibitors in these patients continues to evolve.

\section{Introduction}

Basal cell carcinoma (BCC) is one of the most common malignancies among Caucasians [1]. BCC is typically a slowly growing, locally invasive tumor, with a low metastatic rate (less than $0.5 \%$ ) $[2,3]$, although its incidence has been increasing [1]. Overexposure to ultraviolet radiation from the sun is an important risk factor for the development of BCC $[1,4]$. Other risk factors for BCC include increasing age, male sex, prior arsenic exposure, fair skin type, and immunosuppression [5].

Most cases of BCC are treatable if caught sufficiently early [3]. Infrequently, patients with BCC present with lesions not amenable to surgery or radiation therapy and/or lesions that are locally advanced, invasive, or metastatic; these lesions are referred to by some as advanced BCC $[2,4]$. In addition, locally advanced BCC (laBCC) can be classified by histology as aggressive or nonaggressive. Aggressive histologies range from less aggressive subtypes (such as nodular BCC) to those of more aggressive subtypes (morpheaform, infiltrated, sclerosing, or basosquamous) [6]. Other factors may affect the complexity of BCC and subsequent management decisions, such as lesion size and location: a lesion amenable to surgery on the trunk may be more difficult to treat on the face [4]. Furthermore, challenges associated with the management of BCC include number of lesions and recurrence rates. Cure rates for recurrent lesions are lower than for primary lesions, and the risk of recurrence may remain high even with additional surgery, especially for lesions on the face. Finally, the presence of genodermatoses affects disease management, as these syndromes give rise to multiple and recurrent lesions. Genodermatoses include BCC nevus syndrome (BCCNS), xeroderma pigmentosum, Bazex-Dupré-Christol syndrome, and Rombo syndrome.

\section{Management of advanced BCC}

Treatment options for BCC depend on lesion type and location, and patient preference, and include surgical excision, Mohs surgery, curettage and electrodessication, radiation therapy, topical treatments (eg, topical 5-fluorouracil, imiquimod), photodynamic therapy, cryotherapy, and systemic drug treatment (Table 1) [7,8]. Each treatment modality has advantages and disadvantages, as well as clinical indications for which it is best suited. Of the options listed in Table 1, hedgehog pathway inhibitors (HHIs) are the sole systemic drug treatment for advanced BCC.

The hedgehog $(\mathrm{HH})$ pathway is involved in organ formation during embryogenesis. Normally, the $\mathrm{HH}$ pathway is dormant in adulthood, but it may be reactivated during conditions in which adult replacement tissue is created or physiologically necessary (eg, taste buds, hair follicles, and wound repair) [9]. It may also be aberrantly activated in several types of cancer. Ligand activation of the cell surface molecule Patched-1 (Ptch1) releases inhibition of Smoothened (Smo), thereby allowing its activation. Smo translocates to and accumulates in the primary cilia, culminating in activation of transcription factors Gli1, Gli2, and Gli3 [9-11]. The relationship between $\mathrm{HH}$ signaling

${ }^{\star}$ Correspondence to: Michael R. Migden, Departments of Dermatology and Head and Neck Surgery, MD Anderson Cancer Center Houston, TX USA, Tel: 713-500-8260; Fax 713-745-3597; E-mail: mrmigden@mdanderson.org

Key words: advanced basal cell carcinoma, hedgehog inhibitor, sonidegib, vismodegib

Received: July 18, 2018; Accepted: August 06, 2018; Published: August 09, 2018 
Table 1. Treatment Options for Basal Cell Carcinoma.

\begin{tabular}{|c|c|c|c|c|}
\hline Treatment & Indications & Advantages & Disadvantages & Histological Assessment \\
\hline Surgical excision [8] & $\begin{array}{l}\text { - Small, well-defined lesions } \\
\text { - Large, low-risk lesions }\end{array}$ & - High cure rate & $\begin{array}{l}\text { - Potential for recurrence } \\
\text { - Contraindicated or impractical in } \\
\text { some cases }\end{array}$ & Postoperative analysis \\
\hline Mohs surgery [8] & $\begin{array}{l}\text { - Large, high-risk, recurrent, and } \\
\text { facial and other tumors }\end{array}$ & $\begin{array}{l}\text { - Very high cure rate } \\
\text { - Preserves healthy tissue } \\
\text { - Minimizes scarring }\end{array}$ & $\begin{array}{l}\text { - Time-consuming procedure } \\
\text { - Requires a specialist }\end{array}$ & $\begin{array}{l}\text { Intraoperative complete en face } \\
\text { margin evaluation }\end{array}$ \\
\hline $\begin{array}{l}\text { Curettage/ } \\
\text { electrodessication [8] }\end{array}$ & - Small, low-risk primary tumors & $\begin{array}{l}\text { - Inexpensive } \\
\text { - Quick procedure }\end{array}$ & $\begin{array}{l}\text { - Wounds heal slowly } \\
\text { - Potential for scarring } \\
\text { - High rate of recurrence with high- } \\
\text { risk lesions }\end{array}$ & Not assessed \\
\hline Radiation $[7,8]$ & $\begin{array}{l}\text { Patients in whom surgery is } \\
\text { otherwise contraindicated or } \\
\text { impractical }\end{array}$ & $\begin{array}{l}\text { - Noninvasive } \\
\text { - Painless }\end{array}$ & $\begin{array}{l}\text { - Low cure rate (vs Mohs surgery) } \\
\text { - Generally reserved for older } \\
\text { patients }\end{array}$ & Not applicable \\
\hline Cryotherapy [7] & - Small, low-risk lesions & $\begin{array}{l}\text { - Low cost } \\
\text { - Can be used when surgery is } \\
\text { contraindicated }\end{array}$ & $\begin{array}{l}\text { - Recurrence rates high } \\
\text { - Longer healing times than sutured } \\
\text { wounds } \\
\text { - Scarring may be severe }\end{array}$ & Not assessed \\
\hline 5-FU $[7,8]$ & $\begin{array}{l}\text { - Low-risk, shallow, superficial } \\
\text { lesions } \\
\text { - Surgery or radiation } \\
\text { contraindicated }\end{array}$ & $\begin{array}{l}\text { - Typically good cosmetic } \\
\text { outcomes } \\
\text { - Inexpensive }\end{array}$ & $\begin{array}{l}\text { - Slow treatment time } \\
\text { - Local AEs } \\
\text { - Low cure rates (vs surgery or } \\
\text { radiation) }\end{array}$ & Not applicable \\
\hline Imiquimod $[7,8]$ & $\begin{array}{l}\text { - Low-risk, shallow, superficial } \\
\text { lesions } \\
\text { - Surgery or radiation } \\
\text { contraindicated }\end{array}$ & $\begin{array}{l}\text { - Typically good cosmetic } \\
\text { outcomes } \\
\text { - Inexpensive }\end{array}$ & $\begin{array}{l}\text { - Slow treatment time } \\
\text { - Local AEs } \\
\text { - Low cure rates (vs surgery or } \\
\text { radiation) }\end{array}$ & Not applicable \\
\hline PDT $[7,8]$ & - Superficial or nodular lesions & $\begin{array}{l}\text { - Typically good cosmetic } \\
\text { outcomes }\end{array}$ & $\begin{array}{l}\text { - Low cure rate (vs surgery) } \\
\text { - Patients remain photosensitive } 1 \\
\text { to } 2 \text { days after treatment }\end{array}$ & Not assessed \\
\hline HHI [8] & $\begin{array}{l}\text { Adult patients with laBCC not } \\
\text { amenable to surgery or radiation; } \\
\text { or with } \mathrm{mBCC}\end{array}$ & $\begin{array}{l}\text { - Effective for laBCC and ex-US } \\
\text { for mBCC }\end{array}$ & $\begin{array}{l}\text { - Not tolerated in some patients due } \\
\text { to low-grade AEs }\end{array}$ & Not applicable \\
\hline
\end{tabular}

AE, adverse event; 5-FU, 5-fluorouracil; HHI, hedgehog inhibitor; laBCC, locally advanced basal cell carcinoma; mBCC, metastatic BCC; PDT, photodynamic therapy.

[Reprinted from Cancer Treat Rev. Vol 64, Migden MR, Chang ALS, Dirix L, Stratigos AJ, Lear JT. Emerging trends in the treatment of advanced basal cell carcinoma. pp1-10, Copyright 2018, with permission from Elsevier]

and human cancer was first noted in patients with BCCNS who had inactivating mutations in Ptch1, causing constitutive activation of $\mathrm{HH}$ signaling in the absence of ligand [11,12]. In BCC, up to $75 \%$ of cases show mutations in Ptchl, indicating a strong role for aberrant $\mathrm{HH}$ signaling in the disease $[11,13]$.

Cyclopamine, a teratogen found in corn lily plants, was the first discovered HH pathway antagonist [14,15]. Cyclopamine binds to Smo, disrupting normal embryonic development. Furthermore, in mouse xenografts, cyclopamine inhibited proliferation and invasion of glioma, melanoma, and colon, pancreatic, and prostate cancers in orthotopic models [16]. Modifications of cyclopamine created a semisynthetic HHI, patidegib, with greater potency and better pharmacokinetics [17]. The discovery of cyclopamine demonstrated that small molecules could inhibit HH. Therefore, the search for more HHIs was undertaken using high-throughput screening, leading to the discovery of vismodegib and sonidegib [18-20]. Using a Gli1 reporter gene assay, itraconazole was discovered to inhibit $\mathrm{HH}$ signaling $[21,22]$. Itraconazole acts by preventing Smo translocalization and accumulation in primary cilia [21]. Vismodegib and sonidegib have been approved in the United States (US) and European Union for the treatment of laBCC; in Australia and Switzerland, both agents are approved treatments for laBCC and metastatic BCC (mBCC) [23-29].

Because the $\mathrm{HH}$ pathway may be activated downstream of Smo, researchers are examining the possibility of inhibiting Gli-mediated transcription directly. To this end, the compounds GANT-58 and GANT-61 were found to suppress Gli-mediated signaling in a reporter gene assay [30]. In tumor xenografts, GANT-61 was found to inhibit proliferation and induce apoptosis [31]. These agents are not yet in clinical trials.

\section{Approved hedgehog inhibitors-clinical data}

\section{Vismodegib}

Vismodegib was approved in the US based on results from the pivotal phase 2, single-arm, nonrandomized, 2-cohort, multicenter trial ERIVANCE [32]. The end points in ERIVANCE were evaluated by investigators and centrally by an independent review facility (IRF) for a total of 21 months (Table 2) [33]. Objective response in ERIVANCE was determined using Response Evaluation Criteria in Solid Tumors (RECIST), assessed by computed tomography or magnetic resonance imaging. ERIVANCE enrolled 104 patients with advanced BCC (71 patients had laBCC; 33 had $\mathrm{mBCC}$ ) who received $150 \mathrm{mg}$ daily. The primary end point of objective response rate (ORR) assessed by IRF was $47.6 \%$ for patients with laBCC and $33.3 \%$ for patients with mBCC. The complete response (CR) and partial response (PR) rates were $22.2 \%$ and $25.4 \%$ for patients with laBCC, respectively. All patients with $\mathrm{mBCC}$ had PR ( $0 \% \mathrm{CR})$. By central review, the median duration of response (mDOR) was 9.5 months (range, 7.4-21.4) and 7.6 months (range, 5.5-9.4) for patients with laBCC and mBCC, respectively. Treatment-emergent adverse events (AEs) included muscle spasms (71.2\%), alopecia (65.4\%), dysgeusia (53.8\%), weight decrease $(50.0 \%)$, fatigue $(40.4 \%)$, and nausea $(32.7 \%)$, of which approximately half (48.1\%) were grade $1-2$.

STEVIE was a single-arm, open-label, multicenter, post-approval trial in 1215 patients (1119 laBCC, $96 \mathrm{mBCC}$ ) receiving vismodegib 150 $\mathrm{mg} /$ day $[34,35]$. The primary end point of this trial was safety, and end points in STEVIE were evaluated only by investigators (Table 2). At 12 months, $12 \%$ of patients were still receiving vismodegib, with TEAEs being the main reason for discontinuation of therapy. The majority of 
Table 2. End Point and Response Criteria Used Across Vismodegib and Sonidegib Trials.

\begin{tabular}{|c|c|c|c|}
\hline & ERIVANCE [32,33] & STEVIE $[34,35]$ & BOLT $[36,37]$ \\
\hline Primary End Point & ORR assessed by an IRF (ie, central review) & Safety by NCI-CTCAE v4.0* & $\begin{array}{l}\text { ORR per central review and confirmed by } \\
\text { independent review committee }\end{array}$ \\
\hline ORR definition & $\begin{array}{l}\text { Composite tumor response criteria: CR or PR } \\
\text { determined on } 2 \text { consecutive assessments }(\geq 4 \\
\text { weeks apart) by RECIST v1. } 0^{\dagger}\end{array}$ & $\begin{array}{l}\text { CR or PR by RECIST v1.1 by investigator } \\
\text { review }\end{array}$ & $\begin{array}{l}\text { Best overall response of CR or PR by } \\
\text { BCC-mRECIST } v 1.1^{*} \text { confirmed on repeat } \\
\text { assessments at visits } \geq 4 \text { weeks apart }\end{array}$ \\
\hline $\mathrm{CR}$ definition (for laBCC) & $\begin{array}{l}\text { For externally visible tumors: Target lesions } \\
\text { no longer visible (by either imaging or } \\
\text { photograph) and negative histology from a } \\
\text { single biopsy } \\
\begin{array}{l}\text { For ulcerated tumors: Re-epithelialization } \\
\text { of entire baseline area of ulceration of target } \\
\text { lesions }\end{array}\end{array}$ & $\begin{array}{l}\text { Disappearance of all target lesions and any } \\
\text { pathological lymph nodes for reduction in } \\
\text { short axis to }<10 \mathrm{~mm}\end{array}$ & $\begin{array}{l}\text { Total resolution of all lesions confirmed on } \\
\text { repeated assessments by all modalities (MRI, } \\
\text { color photography, and histology) and at } \\
\text { least } 2 \text { negative punch biopsies per lesion }\end{array}$ \\
\hline PR definition (for laBCC) & $\begin{array}{l}\text { For externally visible tumors: Unidirectional } \\
\text { decrease from baseline } \geq 30 \% \text { in sum of } \\
\text { longest dimension of target lesions } \\
\text { For ulcerated tumors: No criteria }\end{array}$ & $\begin{array}{l}\geq 30 \% \text { reduction in sum of diameters of target } \\
\text { lesions from baseline }\end{array}$ & $\begin{array}{l}\geq 30 \% \text { reduction in sum of longest } \\
\text { diameters of target lesion(s) per RECIST } \\
\text { v1.1 (imaging assessments) and } \geq 50 \% \\
\text { bidirectional reduction in sum of products of } \\
\text { perpendicular diameters of target lesion(s) } \\
\text { per WHO guidelines (clinical measurements } \\
\text { or measurements by photography of clinical } \\
\text { lesions) }\end{array}$ \\
\hline Secondary End Points & $\begin{array}{l}\text { Investigator-assessed ORR, IRF-assessed } \\
\text { and investigator-assessed DOR and PFS, } \\
\text { and safety }\end{array}$ & $\begin{array}{l}\text { Investigator-assessed ORR (RECIST v1.1), } \\
\text { DOR, TTR, OS, and quality of life }\end{array}$ & $\begin{array}{l}\text { ORR by investigator review; CR rate, TTR, } \\
\text { DOR, and PFS by central and investigator } \\
\text { review and safety }\end{array}$ \\
\hline
\end{tabular}

*Percentage of patients who experienced any AEs, grade 3 or 4 AEs, AEs leading to drug interruptions or discontinuations, or any serious AEs.

'Externally visible component of all target lesions $\geq 10 \mathrm{~mm}$ in longest dimension to facilitate accurate and reproducible measurement; standardized digital photographs of externally visible components of all target lesions obtained; imaging studies (CT or MRI) to assess RECIST component of tumor response and histologic analysis of on-study biopsy specimens to determine CR or PR.

†Potential for post-treatment ulceration, cyst formation, scarring/fibrosis, and ill-defined lesion borders renders RECIST v1.1 inadequate for tumor assessment in patients with laBCC. Note: BCC-mRECIST is a stringent composite multimodal assessment tool that integrates MRI per RECIST v1.1, standard and annotated color photography per bidimensional WHO guidelines, and histology in multiple biopsy specimens surveying the lesion area.

${ }^{\S}$ Quality-of-life results to be reported separately.

AE, adverse event; BCC, basal cell carcinoma; CR, complete response; CT, computed tomography; DOR, duration of response; IRF, independent review facility; laBCC, locally advanced BCC; mRECIST, modified Response Evaluation Criteria in Solid Tumors; MRI, magnetic resonance imaging; NCI-CTCAE, National Cancer Institute Common Terminology Criteria for Adverse Events; ORR, objective response rate; OS, overall safety; PFS, progression-free survival; PR, partial response; RECIST, Response Evaluation Criteria in Solid Tumors; TTR, time to tumor response; WHO, World Health Organization.

patients (98\%) had $\geq 1$ TEAE. The most commonly reported TEAEs occurring at a greater than $20 \%$ incidence were muscle spasms $(66 \%)$, alopecia (62\%), dysgeusia (55\%), decreased weight (41\%), decreased appetite (25\%), and asthenia (24\%). With a median follow-up of 17.9 months, an objective response was documented in $68.5 \%$ (95\% CI, 65.7-71.3) of patients with laBCC (CR 33.4\%) and 36.9\% (95\% CI, 26.6-48.1) of patients with $\mathrm{mBCC}(\mathrm{CR} 4.8 \%)$.

\section{Sonidegib}

In the multicenter, randomized, double-blind, pivotal phase 2 BOLT trial, which resulted in approval of the 200-mg daily dose, responses to treatment were evaluated differently than in ERIVANCE or STEVIE, in that both central and investigator assessments were used throughout the 42-month trial duration (Table 2) [32-37]. The primary end point of BOLT was ORR, consisting of those patients who had either CR or PR, per central review [36]. In BOLT, patients' lesions were evaluated by BCC-modified RECIST (BCC-mRECIST), which is more stringent than the RECIST used in ERIVANCE and STEVIE [38]. BCC-mRECIST is a multimodal tumor assessment method integrating magnetic resonance imaging per RECIST v1.1, standard and annotated color photography per World Health Organization (WHO) guidelines, and histology in multiple biopsy specimens surveying the lesion area [38]. A prespecified sensitivity analysis using an alternative definition for CR (at least a PR according to MRI and/or photography and no evidence of tumor on biopsy of the residual lesion) yielded a CR rate of $21 \%$, similar to that reported in ERIVANCE $[39,40]$.
A total of 230 patients (laBCC, $n=194 ; m B C C, n=36$ ) were treated with sonidegib $(200 \mathrm{mg}$ or $800 \mathrm{mg}$ ) once per day $[36,40]$. In patients with laBCC, at 12 months per central review, ORRs (CR + PR) were $57.6 \%$ and $43.8 \%$ in the $200-\mathrm{mg}$ and $800-\mathrm{mg}$ arms, respectively. The $\mathrm{mDOR}$ (central review) was not reached in patients who received 200 mg but was 15.7 months in the $800-\mathrm{mg}$ arm. In patients with mBCC, ORRs were $7.7 \%$ for the $200-\mathrm{mg}$ arm and $17.4 \%$ for the $800-\mathrm{mg}$ arm. The mDOR was not reached in either group of patients (200-mg or 800-mg). Investigator-reported response rates in patients with laBCC and $\mathrm{mBCC}$ were higher than those determined via central review.

At 30 months in patients with laBCC, the ORRs in the 200-mg arm were $56.1 \%$ (central review) and $71.2 \%$ (investigator review); in the $800-\mathrm{mg}$ arm, ORRs were $45.3 \%$ and $58.6 \%$, respectively. By central review, mDOR was 26.1 months for patients with laBCC and 24.0 months for patients with mBCC. This was similar to the mDOR of 26.2 months for laBCC (investigator reviewed) but longer than the $\mathrm{mDOR}$ of 14.8 months for mBCC reported for vismodegib in ERIVANCE at 39 months' follow-up (investigator reviewed) [41]. At 30 months, patients with mBCC ORRs in the 200 -mg arm were $7.7 \%$ (central review) and $23.1 \%$ (investigator review); in the 800 -mg arm, the ORRs were $17.4 \%$ (central review) and $34.8 \%$ (investigator review), respectively [40]. The majority of AEs reported were grades 1 and 2 (57\%). The most frequent AEs leading to treatment discontinuation were muscle spasm $(5.1 \%$ in the 200 -mg group vs $8 \%$ in the 800 -mg group), weight decreased $(2.5 \%$ vs $6 \%$ ), dysgeusia ( $3.8 \%$ vs $4.7 \%$ ), and alopecia ( $1.3 \%$ vs $6 \%$ ). 


\section{Other hedgehog inhibitors for basal cell carcinoma}

Taladegib (LY2940680) is a novel Smo antagonist in early stage clinical trials for advanced BCC and other solid tumors [42]. In a phase 1 trial of 84 patients with laBCC or mBCC (NCT01226485), responses were observed in patients, whether HHI-naive (11 of 16 patients) or previously treated with an HHI (11 of 31 ). Four patients had events considered dose limiting.

Patidegib (saridegib, IPI-926) is a novel HHI in development for topical administration in BCCNS (NCT02762084). In vivo studies on depilated mice showed that $2 \%$ topical patidegib inhibited Gli1 and Ptch 1 mRNA by $50 \%$ to $60 \%$ [43].

As previously mentioned, itraconazole inhibits the translocation and accumulation of Smo in the primary cilium [21,22]. In an exploratory phase 2 trial of 29 patients with BCC (each of whom had at least one lesion greater than $4 \mathrm{~mm}$ in diameter), itraconazole was effective: of 19 treated patients, four achieved a PR and four achieved stable disease (SD) [44]. Further, on average, in vismodegib-naive patients, itraconazole reduced tumor area by $24 \%$ (95\% CI, 18.2\%-30.0\%).

Posaconazole is a second-generation triazole that, like itraconazole, inhibits the $\mathrm{HH}$ pathway [45]. Posaconazole demonstrated activity against Smo-mutant cell lines and synergized with vismodegib in $\mathrm{HH}$ dependent models. It is not yet in clinical trials for efficacy in cancer treatment.

\section{Resistance to hedgehog inhibitors}

Of patients who failed to respond to vismodegib in ERIVANCE, it is possible that failure was due in part to spontaneous mutations in Smo [46]. Research has identified several mutations in Smo giving rise to HHI resistance [47,48]. For example, a mutation at residue 518 of Smo increased binding affinity for sonidegib and decreased binding affinity for vismodegib [49,50]. Also, the D427H mutation of Smo disrupted binding between sonidegib and Smo protein and changed the conformation of its transmembrane domain [51]. The $\mathrm{D} 473 \mathrm{H}$ mutation alters the conformation of Smo such that the HHIs vismodegib and sonidegib can no longer bind with sufficient affinity to inhibit Smo activity. Using X-ray crystallographs to model changes in Smo, a molecule with HHI activity that would not lose activity in the presence of the D473H mutation (LEQ-506) was developed. LEQ-506 has not yet been tested for efficacy.

Smo mutations were identified in 22 of 44 clinical specimens resistant to HHIs obtained from patients with BCC [52]. In a case report, resistance to vismodegib developed in a patient with BCC; genomic analysis revealed that the recurrent lesions had two different mutations in Smo. In some instances, multiple mutations causing resistance have been observed within the same tumor, as identified by genomic analysis [53]. Resistance was observed in two patients with laBCC or BCCNS who were treated with vismodegib, which was discontinued to manage AEs. When the drug was restarted, however, efficacy was lost [54]. To examine retreatment with HHIs in detail, a set of 6 patients enrolled in STEVIE who discontinued vismodegib due to progressive disease were tried on a second course of vismodegib [55]. The ORR was $80 \%$ on the first course and $50 \%$ for the second course in this set of patients. The authors concluded that retreatment with the same HHI is feasible and that the same drug may have activity after initial disease progression.

One patient with laBCC resistant to vismodegib responded to a combination of sonidegib and itraconazole [56]. This case is especially noteworthy because the patient presented with intracranial, inoperable advanced BCC involving the sinuses and brain. Itraconazole may have additional antineoplastic effects, such as angiogenesis inhibition and inducing cell cycle arrest [22]. Itraconazole plus arsenic trioxide also induced SD in 3 of 4 patients with $\mathrm{mBCC}$ who completed 3 cycles of drug [57].

The role of the phosphoinositide 3-kinase (PI3K) pathway in promoting resistance to HHIs has also been studied [58]. In a proof of concept study in smoothened inhibitor-resistant patients with advanced BCC, the majority (5 of 7 evaluable patients) had either a PR $(n=1)$ or SD $(n=4)$ when given sonidegib plus the PI3K inhibitor buparlisib [59]. However, this study was terminated early due to toxicity of the combination.

Besides combining distinct HHIs or an HHI with a drug having a different mechanism of action, it may be feasible to target $\mathrm{HH}$ components downstream of Smo, such as Gli1/2 as described above with GANT-61 [59]. Exploratory research in this area is underway, as is work on other compounds that inhibit Smo through mechanisms differing from those of currently approved HHIs [60,61].

\section{Conclusions and future directions}

As HHIs continue to be used for advanced BCC, the question of overcoming resistance to them will be of increasing importance. In addition to targeting mediators downstream of Smo and using novel combinations of drugs that suppress more than one signaling pathway, using the body's immune system may also be an emerging treatment option. Anti-programmed death-1 (PD-1) immunotherapy was successfully used for a patient with $\mathrm{mBCC}$ who could not tolerate HHIs [62]. Furthermore, the use of HHIs as neoadjuvant therapy is under investigation [63]. There remains much to be learned regarding the optimal use of HHIs in BCC.

\section{Acknowledgment}

Medical writing support was provided by Beverly E. Barton, $\mathrm{PhD}$, ScioScientific, LLC.

Table 1 reprinted from Cancer Treat Rev. Vol 64, Migden MR, Chang ALS, Dirix L, Stratigos AJ, Lear JT. Emerging trends in the treatment of advanced basal cell carcinoma. pp1-10, Copyright 2018, with permission from Elsevier.

\section{Source of economic support}

Publication of this review was supported by Sun Pharmaceutical Industries, Ltd.

\section{Conflict of interest}

The author received no compensation for writing this article. Dr. Migden has participated on advisory boards with, and received honoraria from, Genentech, Inc., Novartis Pharmaceuticals Corporation, Sun Pharmaceutical Industries, Ltd., Eli Lilly \& Company, and Regeneron Pharmaceuticals.

\section{References}

1. Samarasinghe V, Madan V (2012) Nonmelanoma skin cancer. J Cutan Aesthet Surg 5 3-10. [Crossref]

2. Puig S, Berrocal A (2015) Management of high-risk and advanced basal cell carcinoma Clin Transl Oncol 17: 497-503. [Crossref]

3. Lanoue J, Goldenberg G (2016) Basal cell carcinoma: a comprehensive review of existing and emerging nonsurgical therapies. J Clin Aesthet Dermatol 9: 26-36. 
4. Lear JT, Corner C, Dziewulski P, Fife K, Ross GL, et al. (2014) Challenges and new horizons in the management of advanced basal cell carcinoma: a UK perspective. $\mathrm{Br} \mathrm{J}$ Cancer 111: 1476-1481. [Crossref]

5. Telfer NR, Colver GB, Morton CA; British Association of Dermatologists (2008) Guidelines for the management of basal cell carcinoma. Br J Dermatol 159: 35-48. [Crossref]

6. Lewin JM, Carucci JA (2015) Advances in the management of basal cell carcinoma. F1000Prime Rep 7: 53. [Crossref]

7. Kauvar AN, Cronin T Jr, Roenigk R, Hruza G, Bennett R, et al. (2015) Consensus for nonmelanoma skin cancer treatment: basal cell carcinoma, including a cost analysis of treatment methods. Dermatologic Surgery 41: 550-571. [Crossref]

8. Migden MR, Chang ALS, Dirix L, Stratigos AJ, Lear JT (2018) Emerging trends in the treatment of advanced basal cell carcinoma. Cancer Treat Rev 64: 1-10. [Crossref]

9. Scales SJ, de Sauvage FJ (2009) Mechanisms of Hedgehog pathway activation in cancer and implications for therapy. Trends Pharmacol Sci 30: 303-312. [Crossref]

10. Gupta S, Takebe N, Lorusso P (2010) Targeting the Hedgehog pathway in cancer. Ther Adv Med Oncol 2: 237-250. [Crossref]

11. Li C, Chi S, Xie J (2011) Hedgehog signaling in skin cancers. Cell Signal 23: 12351243. [Crossref]

12. Peukert S, Miller-Moslin K (2010) Small-molecule inhibitors of the hedgehog signaling pathway as cancer therapeutics. ChemMedChem 5: 500-512. [Crossref]

13. Pellegrini C, Maturo MG, Di Nardo L, Ciciarelli V, Gutiérrez García-Rodrigo C, et al. (2017) Understanding the molecular genetics of basal cell carcinoma. Int J Mol Sci 18: 2485.

14. Cooper MK, Porter JA, Young KE, Beachy PA (1998) Teratogen-mediated inhibition of target tissue response to Shh signaling. Science 280: 1603-1607.

15. Heretsch P, Tzagkaroulaki L, Giannis A(2010) Cyclopamine and hedgehog signaling: chemistry, biology, medical perspectives. Angew Chem Int Ed Engl 49: 3418-3427. [Crossref]

16. Rimkus TK, Carpenter RL, Qasem S, Chan M, Lo HW (2016) Targeting the sonic hedgehog signaling pathway: review of smoothened and GLI inhibitors. Cancers (Basel) 8: E22. [Crossref]

17. Tremblay MR, Lescarbeau A, Grogan MJ, Tan E, Lin G, et al. (2009) Discovery of a potent and orally active hedgehog pathway antagonist (IPI-926). $J$ Med Chem 52: 4400-4418. [Crossref]

18. Robarge KD, Brunton SA, Castanedo GM, Cui Y, Dina MS, et al. (2009) GDC-0449-a potent inhibitor of the hedgehog pathway. Bioorg Med Chem Lett 19: 5576-5581. [Crossref]

19. Pan S, Wu X, Jiang J, Gao W, Wan Y, et al. (2010) Discovery of NVP-LDE225, a poten and selective smoothened antagonist. ACS Med Chem Lett 1: 130-134. [Crossref]

20. Gould SE, Low JA, Marsters JC Jr, Robarge K, Rubin LL, et al. (2014) Discovery and preclinical development of vismodegib. Expert Opin Drug Discov 9: 969-984. [Crossref]

21. Kim J, Tang JY, Gong R, Kim J, Lee JJ, et al. (2010) Itraconazole, a commonly used antifungal that inhibits Hedgehog pathway activity and cancer growth. Cancer Cell 17 : 388-399. [Crossref]

22. Pounds R, Leonard S, Dawson C, Kehoe S (2017) Repurposing itraconazole for the treatment of cancer. Oncol Lett 14: 2587-2597. [Crossref]

23. Odomzo (2017) Sun Pharmaceutical Industries, Inc., Cranbury, NJ.

24. European Medicines Agency. Odomzo. Summary of Product Characteristics. http://www.emaca.europa.eu/docs/en_GB/document_libraaary/EPAR_-_Product_ Information/humaan/002839/WC500192970.pdf. Accessed February 23, 2018.

25. Odomzo (2017) Sun Pharma ANZ Pty Ltd, Macquarie Park, NSW, Australia.

26. Swissmedic. Odomzo 200mg, Kapseln (Sonidegibum). Authorization Number 65065, 2015. https://www.swissmedic.ch/swissmedic/de/home/humanarzneimittel/ authorisations/new-medicines/odomzo--200mg--kapseln--sonidegibum-.html. Accessed June 13, 2018.

27. Erivedge (2017) Genentech, South San Francisco, CA.

28. Erivedge (2013) Roche Products Pty Limited, Dee Why, NSW, Australia.

29. European Medicines Agency. Erivedge. Summary of Product Characteristics. http:// www.ema.europa.eu/ema/index.jsp?curl=pages/medicines/human $/$ medicines $/ 002602 /$ human_med_001659.jsp\&mid=WC0b01ac058001d124. Accessed June 13, 2018.

30. Lauth M, Bergström A, Shimokawa T, Toftgård R (2007) Inhibition of GLI-mediated transcription and tumor cell growth by small-molecule antagonists. Proceedings of the National Academy of Sciences of the United States of America, 104: 8455-8460. [Crossref]
31. Srivastava RK, Kaylani SZ, Edrees N, Li C, Talwelkar SS, et al. (2014) GLI inhibitor GANT-61 diminishes embryonal and alveolar rhabdomyosarcoma growth by inhibiting Shh/AKT-mTOR axis. Oncotarget 5: 12151-12165. [Crossref]

32. Sekulic A, Migden MR, Oro AE, Dirix L, Lewis KD, et al. (2012) Efficacy and safety of vismodegib in advanced basal-cell carcinoma. N Engl J Med 366: 2171-2179. [Crossref]

33. Sekulic A, Migden MR, Lewis K, Hainsworth JD, Solomon JA, et al. (2015) Pivotal ERIVANCE basal cell carcinoma (BCC) study: 12-month update of efficacy and safety of vismodegib in advanced BCC. J Am Acad Dermatol 72: 1021-1026. [Crossref]

34. Basset-Séguin N, Hauschild A, Grob JJ, Kunstfeld R, Dréno B, et al. (2015) Vismodegib in patients with advanced basal cell carcinoma (STEVIE): a pre-planned interim analysis of an international, open-label trial. Lancet Oncol 16: 729-736. [Crossref]

35. Basset-Séguin N, Hauschild A, Kunstfeld R, Grob J, Dréno B, et al. (2017) Vismodegib in patients with advanced basal cell carcinoma: primary analysis of STEVIE, an international, open-label trial. Eur J Cancer 86: 334-348. [Crossref]

36. Dummer R, Guminski A, Gutzmer R, Dirix L, Lewis KD, et al. (2016) The 12-month analysis from Basal Cell Carcinoma Outcomes with LDE225 Treatment (BOLT): A phase II, randomized, double-blind study of sonidegib in patients with advanced basal cell carcinoma. J Am Acad Dermatol 75: 113-125.e5. [Crossref]

37. Migden MR, Guminski A, Gutzmer R, Dirix L, Lewis KD, et al. (2015) Treatment with two different doses of sonidegib in patients with locally advanced or metastatic basal cell carcinoma (BOLT): a multicentre, randomised, double-blind phase 2 trial. Lancet Oncol 16: 716-728. [Crossref]

38. Eisenhauer EA, Therasse P, Bogaerts J (2009) New response evaluation criteria in solid tumours: revised RECIST guideline (version 1.1). Eur J Cancer 45: 228-247. [Crossref]

39. Migden MR, Lewis KD (2018) 42-Month follow-up of sonidegib efficacy and safety in advanced basal cell carcinoma: final analysis from BOLT. J Clin Oncol 36: (Suppl) Abstract 9551 .

40. Lear JT, Migden MR, Lewis KD, Chang ALS, Guminski A, et al. (2018) Long-term efficacy and safety of sonidegib in patients with locally advanced and metastatic basal cell carcinoma: 30-month analysis of the randomized phase 2 BOLT study. J Eur Acad Dermatol Venereol 32: 372-381. [Crossref]

41. Sekulic A, Migden MR, Basset-Seguin N, Garbe C, Gesierich A, et al. (2017) Longterm safety and efficacy of vismodegib in patients with advanced basal cell carcinoma: final update of the pivotal ERIVANCE BCC study. BMC Cancer 17: 332. [Crossref]

42. Bendell J, Andre V, Ho A, Kudchadkar R, Migden M, et al. (2018) Phase I study of LY2940680, a Smo antagonist, in patients with advanced cancer including treatment-naïve and previously treated basal cell carcinoma. Clin Cancer Res 24: 2082-2091. [Crossref]

43. Lauressergues E, Heusler P, Lestienne F, Troulier D, Rauly-Lestienne I, et al. (2016) Pharmacological evaluation of a series of smoothened antagonists in signaling pathways and after topical application in a depilated mouse model. Pharmacol Res Perspect 4: e00214. [Crossref]

44. Kim DJ, Kim J, Spaunhurst K, Montoya J, Khodosh R, et al. (2014) Open-label, exploratory phase II trial of oral itraconazole for the treatment of basal cell carcinoma. J Clin Oncol 32: 745-751. [Crossref]

45. Chen B, Trang V, Lee A, Williams NS, Wilson AN, et al. (2016) Posaconazole, a second-generation triazole antifungal drug, inhibits the hedgehog signaling pathway and progression of basal cell carcinoma. Mol Cancer Ther 15: 866-876. [Crossref]

46. Danial C, Sarin KY, Oro AE, Chang AL (2016) An investigator-initiated open-label trial of sonidegib in advanced basal cell carcinoma patients resistant to vismodegib. Clin Cancer Res 22: 1325-1329. [Crossref]

47. Brinkhuizen T, Reinders MG, van Geel M, Hendriksen AJ, Paulussen AD, et al. (2014) Acquired resistance to the Hedgehog pathway inhibitor vismodegib due to smoothened mutations in treatment of locally advanced basal cell carcinoma. J Am Acad Dermatol 71: 1005-1008. [Crossref]

48. Pricl S, Cortelazzi B, Dal Col V, Marson D, Laurini E, et al. (2015) Smoothened (SMO) receptor mutations dictate resistance to vismodegib in basal cell carcinoma. Mol Oncol 9: 389-397. [Crossref]

49. Wang C, Wu H, Evron T, Vardy E, Han GW, et al. (2014) Structural basis for Smoothened receptor modulation and chemoresistance to anticancer drugs. Nat Commun 5: 4355. [Crossref]

50. Chen L, Aria AB, Silapunt S, Lee HH, Migden MR (2018) Treatment of advanced basal cell carcinoma with sonidegib: perspective from the 30-month update of the BOLT trial. Future Oncol 14: 515-525. [Crossref]

51. Tu J, Li JJ, Song LT, Zhai HL, Wang J, et al. (2018) Molecular modeling study on resistance of WT/D473H SMO to antagonists LDE-225 and LEQ-506. Pharmacol Res 129: 491-499. [Crossref] 
52. Atwood SX, Sarin KY, Whitson RJ, Li JR, Kim G, et al. (2015) Smoothened variants explain the majority of drug resistance in basal cell carcinoma. Cancer Cell 27: 342 353. [Crossref]

53. Sharpe HJ, Pau G, Dijkgraaf GJ, Basset-Seguin N, Modrusan Z, et al. (2015) Genomic analysis of smoothened inhibitor resistance in basal cell carcinoma. Cancer Cell 27 : 327-341. [Crossref]

54. Banvolgyi A, Lorincz K, Kiss N, Gyongyosi N, Marton D, et al. (2017) Experiences with SMO antagonist vismodegib for the treatment of locally advanced basal cell carcinoma. J Invest Dermatol 137(Suppl 2): Abstract 035.

55. Alfieri S, Bergamini C, Granata R, Locati L, Licitra L, et al. (2018) Retreatment with vismodegib after progression in advanced basal cell carcinoma: first-time report of a single-institution experience. Target Oncol 13: 253-256. [Crossref]

56. Yoon J, Apicelli AJ, Pavlopoulos TV (2017) Intracranial regression of an advanced basal cell carcinoma using sonidegib and itraconazole after failure with vismodegib. JAAD Case Rep 4: 10-12. [Crossref]

57. Ally MS, Ransohoff K, Sarin K, Atwood SX, Rezaee M, et al. (2016) Effects of combined treatment with arsenic trioxide and itraconazole in patients with refractory metastatic basal cell carcinoma. JAMA Dermatol 152: 452-456. [Crossref]
58. Buonamici S, Williams J, Morrissey M, Wang A, Guo R, et al. (2010) Interfering with resistance to smoothened antagonists by inhibition of the PI3K pathway in medulloblastoma. Sci Transl Med 2: 51ra70. [Crossref]

59. Tran DC, Moffat A, Brotherton R, Pague A, Zhu GA, et al. (2018) An exploratory openlabel, investigator-initiated study to evaluate the efficacy and safety of combination sonidegib and buparlisib for advanced basal cell carcinomas. J Am Acad Dermatol 78: 1011-1013.e3. [Crossref]

60. Gonnissen A, Isebaert S, Haustermans K (2015) Targeting the Hedgehog signaling pathway in cancer: beyond Smoothened. Oncotarget 6: 13899-13913. [Crossref]

61. Jung B, Messias AC, Schorpp K, Geerlof A, Schneider G, et al. (2016) Novel small molecules targeting ciliary transport of Smoothened and oncogenic Hedgehog pathway activation. Sci Rep 6: 22540. [Crossref]

62. Borradori L, Sutton B, Shayesteh P, Daniels GA (2016) Rescue therapy with antiprogrammed cell death protein 1 inhibitors of advanced cutaneous squamous cell carcinoma and basosquamous carcinoma: preliminary experience in five cases. $\mathrm{Br} \mathrm{J}$ Dermatol 175: 1382-1386. [Crossref]

63. Ally MS, Aasi S, Wysong A, Teng C, Anderson E, et al. (2014) An investigator-initiated open-label clinical trial of vismodegib as a neoadjuvant to surgery for high-risk basa cell carcinoma. JAAD 71: 904-911.e1. [Crossref]

Copyright: $\odot 2018$ Migden MR. This is an open-access article distributed under the terms of the Creative Commons Attribution License, which permits unrestricted use, distribution, and reproduction in any medium, provided the original author and source are credited. 